\title{
Going Ape: interview with Brandon Haught
}

\author{
Glenn Branch
}

\begin{abstract}
Brandon Haught, author of Going Ape: Florida's Battles over Evolution in the Classroom, is interviewed about his book.
\end{abstract}

Keywords: Teaching evolution; Brandon Haught; Florida; Creationism

Brandon Haught's Going Ape: Florida's Battles over Evolution in the Classroom (Figure 1) (Gainesville [FL]: University Press of Florida, 2014) is a unique contribution to the literature. It is the only study of controversies over the teaching of evolution that concentrates on a single state over the course of almost a century, starting when William Jennings Bryan launched his national antievolution crusade from his retirement home in 1921. It is also unique in devoting sustained attention to the ins and outs of local school boards and state legislatures as they consider antievolution policies and legislation. But Going Ape isn't a solemn treatment of interest only to academics. A born storyteller, Haught offers interesting, lively, and well-paced accounts of the events he describes, providing a satisfying survey of a controversy with deep historical roots that continues to affect science education even today.

You became interested in the history of Florida's struggles over evolution education while active in such a struggle yourself, as the communications director of the grassroots organization Florida Citizens for Science. How did that interest blossom into a book, though?

It started as pure curiosity. I documented what Florida Citizens for Science was doing for basic historical purposes, and that led to the natural question of "did anything like this ever happen in Florida before?" Basic sleuthing turned up a few interesting historical nuggets. That led to more research that led to more discoveries. In short order, I had a teetering pile of news clippings, school board meeting minutes, audio and video recordings and other documents. Through this research, I realized that no one had ever glimpsed history through this amazing and unique window I had haphazardly revealed. What else could I do but tell the story that was there?

\section{The first wave of the creationist movement involved attempts to ban evolution. How close did Florida-William Jennings Bryan's adopted home-come to doing so?}

Florida antievolutionists fell short of their prize despite multiple attempts in the 1920s, but the win/loss tally is actually of secondary interest. The glorious battles in the state legislature waged by morality crusaders who truly believed "evolution is a danger at our door" are what make this history so engrossing. Take a look at the language used in one of the proposed bills: "It shall be unlawful to teach as fact in any school supported in whole or in part by public funds in this state any theory that denies the existence of God, that denies the Divine creation of man, or to teach in any way atheism or infidelity." The fight over that bill was so heated that all other business in the Florida House ground to a full stop at one point and forced the presiding officer to try, futilely, to clear the rowdy chamber at midnight. Think about that for a minute. A single topic out of all the subjects taught in all the schools across the state so enflamed passions that a room full of lawmakers neglected all of their other important business. "It remains to be seen whether the lives of our children should be blighted by the teaching of evolution," one said. And that was just the beginning of Florida's decades-long infatuation with evolution in the schools. The fight carries on today regardless of who wins or loses. 


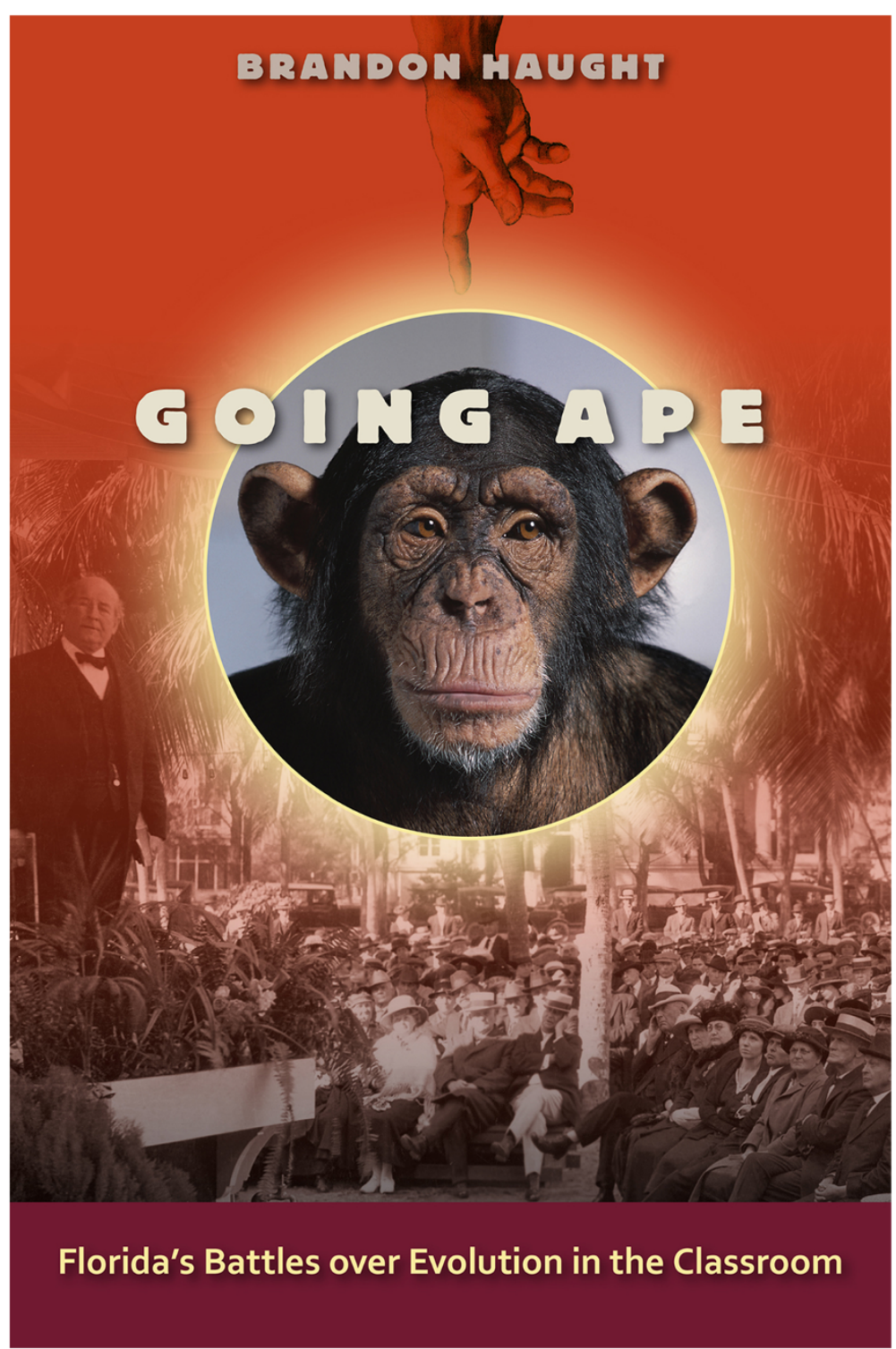

Figure 1 Going Ape: Florida's Battles over Evolution in the Classroom.

Histories of the creationism/evolution controversy often depict the period between Scopes and Sputnik as quiet, so it was particularly interesting to see the discussion of the advice that the Florida department of education was offering teachers about teaching evolution in 1948. What was that advice? Was it good advice for its time? Would it be good advice now?

The Department of Education published A Brief Guide to the Teaching of Science in the Secondary Schools that included a section on "The Book of Genesis, and Science." Despite this relatively quiet time in the evolution wars, as you noted, teachers were nonetheless dealing with some students who saw a "conflict between interpretations of the text books of science and the Book of Genesis in the Old Testament of The Bible." The advice was simple: "Science does not deny God, but it attempts to explain His handiwork." Religious people shouldn't dismiss science and scientists shouldn't dismiss religion, the guide said quite authoritatively. To do so would result in detrimental gaps in the individual's overall knowledge and understanding of the world. While I think that the advice was well-intentioned, after spending years researching and writing Going Ape I have to say that I think that it was ineffective then and would be ineffective now. No matter how anti-evolutionists of today try to hide their intentions, they clearly have the same religious preconceptions as their 1920s counterparts. The science means absolutely 
nothing to them. All they can see is a theory that "denies the Divine creation of man." My book is full of examples of evolution bearing the brunt of the blame for children's immoral conduct. Of course, I know there are plenty of religious people who accept evolution and see no conflict between their beliefs and the science. But the 1948 advice that religious people shouldn't dismiss science falls on the deaf ears of those who fight against the teaching of evolution today and in decades past. It just doesn't touch on their morality crusade.

\section{A highlight of Going Ape is the detailed description of the Hillsborough County School Board's 1980 adoption of a policy requiring equal time for "scientific creationism." Can you say a bit about its rise and fall?}

It started with a determined retired chaplain who regularly toured school board meetings in a few neighboring counties. For years, he tried to get the boards to counterbalance evolution with some form of creationism. Finally, he struck a chord with a majority bloc of Hillsborough County board members. Once they voted to teach scientific creationism alongside evolution, the school district sank into chaos. I'm still amazed how much power duly elected yet misinformed school board members can have. The entire science department fought against the policy, but the board members were so sure of themselves that the protests never stood a chance. The committee assembled to create a curriculum was locked in constant conflict as its members fought over every single thing, big or small. There was even a fight over whether Charles Darwin should be called a scientist. Their final product was such a convoluted mess that the director of the Biological Sciences Curriculum Study in Boulder, Colorado, wrote a letter to the Hillsborough schools science supervisor to express his exasperation. He said it "comes across as completely incomprehensible." But the board was happy and all set to move the new curriculum into the classroom. That's when the federal court decision in McLean v. Arkansas, which ruled that mandated balanced treatment for creation science was unconstitutional, derailed Hillsborough's implementation. The school board reluctantly tabled the curriculum and it was never mentioned again. It's sad that so much time and energy was wasted on a project that should never have started in the first place.

\section{After teaching "scientific creationism" in the public schools was ruled to be unconstitutional, creationists turned to "intelligent design" instead. How far were they successful in Florida?}

There were a couple of feeble attempts to get intelligent design rolling in the state legislature and at the local level, but they never got any traction. Despite the fact that the intelligent design book Of Pandas and People was co-authored by a Floridian, the concept was a dud here.

Florida Citizens for Science was formed in 2005, and that's when you yourself became active in defending the teaching of evolution in Florida. What have the main challenges to evolution education been over the last decade?

I think the newest method of challenging evolution education that has dominated the past decade is the most difficult and frustrating to defend against yet. It's the "academic freedom" strategy, which is closely related to the "teach all of evolution's strengths and weaknesses" ploy. The main advocates of this strategy want to protect teachers from any "retaliation" should they choose to discuss "other theories" during evolution lessons. Of course, they refuse to say what these other theories are. One state senator said teachers can compare evolution to "nonevolution" or "a theory of whatever" and then let students decide what makes sense to them. The strategy takes advantage of citizens' natural desire for fairness. Evolution advocates were painted as dictators who refuse to allow anyone to dare question the sacred dogma of evolution. One lawmaker's favorite refrain was: If the evidence for evolution is so solid then why are scientists so afraid to allow students to question it? An ironically named "academic freedom" proposal was considered for inclusion in a brand new version of the state science standards in 2008 but didn't make it in. Before we could even knock the dings out of our shields after that battle, lawmakers took up the "academic freedom" banner in the state legislature. That exhausting battle raged all the way to the final day of the session. The anti-evolutionists are pretty careful about not bringing religion into their arguments, which makes defending against their "fairness" ploy very difficult at times.

\section{And what was the outcome of those struggles? Have they been resolved satisfactorily, or are there still lingering problems?}

After the headline-grabbing spectacles in 2008, there were a couple of half-hearted follow-up attempts to push "academic freedom," but nothing that was anywhere near as dramatic as the 2008 efforts. But you're right to ask about lingering problems. The prominent players from 2008 are still around and new players, who are signaling an interest in starting the next fight, are popping up. I'm warning my publisher that an updated edition of my book will eventually be needed. New chapters certainly will be added. 
With the recent debate between Bill Nye "The Science Guy" and Ken Ham of Answers in Genesis still in vivid memory, the accounts of the formal debates in Florida between creationists and scientists, such as the debate between the creationist Duane T. Gish of the Institute for Creation Research and the anthropologist Lorena Madrigal of the University of Southern Florida, were fascinating. Did such debates seem to have a good or a bad effect on the public understanding of science in the state?

I don't know how Nye felt after his debate at the Creation Museum, but I corresponded with Madrigal, and I know she felt used and vowed never to participate in such an event again. That was partly because the audience was packed with creationists. Likewise, a Tampa debate in 1974 was well attended because Christian organizations bused in supporters from out of town, many of them teens from Christian youth camps. When reporters covering the debates questioned attendees, it was clear no minds were changed. Madrigal said, "I did not educate a single person."

\section{Florida is considering adopting the Next}

Generation Science Standards, a step endorsed by Florida Citizens for Science. Owing to their treatment of evolution, there's been resistance to the NGSS in Kentucky (where a legislative committee tried to derail their adoption) and Kansas (where a creationist group filed a lawsuit to block their adoption). Have you seen, or do you anticipate, such resistance in Florida?

I guarantee that we'll have a fight on our hands. Activists have been vocal in opposition to Florida's adoption of the Common Core state standards, which cover mathematics and language arts. Organized groups have petitioned school boards to drop the use of a perfectly good world history book because they feel, erroneously, that it promotes Islam while neglecting Christianity and Judaism. Oh yes, there will be resistance to the NGSS.

Although you're not working as a biology teacher yourself, you're trained as a biology teacher, with a college degree in biology education and a state biology teaching certificate. With that training and in the light of your research, what's the most important advice you'd give to teachers facing pressure to downplay evolution or to include "alternatives" to it in their classrooms?

The annual curriculum is so packed with benchmarks that biology teachers are required to teach that I can't imagine there's time to cram evolution "alternatives" in there anywhere. But I'm sure there are some that figure out a way. What happens more often is that teachers push evolution down the schedule and then, whoops, suddenly there is barely time left in the year to give it more than a brief mention. It doesn't happen in all classrooms, of course, but I believe it happens in too many. I know that in my college courses evolution was woven throughout the course from beginning to end. Optimally, that is how it should be done in high school, too, rather than packaging evolution into a handful of lessons given in one week. Setting that daydream of mine aside, teachers can resist pressure to downplay evolution by pointing to the state science standards. We fought hard to maintain evolution's prominence in them. The teacher can simply say, "I'm required to teach it and I would do a disservice to my students if I don't since they are going to see it on state-mandated standardized tests." I know that the solution isn't always going to be that simple, but it's a good place to start.

Received: 6 March 2014 Accepted: 9 March 2014

Published online: 06 June 2014

doi:10.1186/s12052-014-0014-3

Cite this article as: Branch: Going Ape: interview with Brandon Haught. Evolution: Education and Outreach 2014 7:14

Submit your manuscript to a SpringerOpen ${ }^{\odot}$ journal and benefit from:

- Convenient online submission

- Rigorous peer review

- Immediate publication on acceptance

- Open access: articles freely available online

- High visibility within the field

- Retaining the copyright to your article

Submit your next manuscript at $\gg$ springeropen.com 